\title{
Multivariate Analysis of Genetic Divergent of Ethiopian Mustard (Brasica carinata A. Braun) Landraces in Relation to Leafy Vegetative Agro morphological Traits
}

\author{
${ }^{1 *}$ Fekadu Amsalu, ${ }^{2}$ Sentayehu Alamerew, ${ }^{1}$ Bulcha Woyessa \\ ${ }^{1}$ Holetta Agricultural Research Center P. O. Box 2003, Addis Ababa, Ethiopia \\ ${ }^{2}$ Department of Plant science and Horticulture, Jimma University P. O. Box 307, Jimma, Ethiopia
}

\begin{abstract}
The experiment was carried out to assess the extent and patterns of genetic variability of Ethiopian mustard land races in relation to topped plant seed yield and its related leafy vegetative traits at Holetta Agricultural research Center, Ethiopia. Information on the leaves of morphological traits of Ethiopian mustards as a leaf vegetable crop is lacking specifically that of time of defoliation to get dual purpose of the crop (leaf and seed). Therefore forty nine genotypes of Ethiopian mustard land races collected from different agro ecologies were evaluated for agro morphological traits in order to assess the genetic diversity that exists among these materials. The experiment was carried out in a simple lattice design. Univariate analysis of variance showed that there were significant differences among genotypes for leaf length, Length of Petiole, leaf width and leaf area traits but seed yield per plant leaf topped at $40^{\text {th }}$, 50th and $60^{\text {th }}$ growth stages of days of topping, leaf weight per plant topped to these similar days of topping and number of intact leaves at flowering showed non-significant differences. The significant difference indicates the existence of genetic variability among the accessions which is important for improvement of these traits. Average weight of $2.7 \mathrm{~g}$ of seed yield per plant of defoliated could be attained by utilization of leaves in the $50^{\text {th }}$ day of growth stage of topping. Multivariate analyses resulted in the formation of four clusters and have shown the presence of substantial genetic diversity among the genotypes. The present study revealed the presence of considerable variability among genotypes for leaf length, Length of Petiole, leaf width and leaf area traits except seed yield per plant, leaf biomass per plant topped at $40^{\text {th }}, 50^{\text {th }}$ and $60^{\text {th }}$ growth stage days of topping and number of intact leaves at flowering. The significant difference of results indicates that the presence of good opportunity to improve these characters using the tested genotypes.
\end{abstract}

Keywords: Ethiopian mustard, Genetic diversity, leaf morphological traits univariate analysis, multivariate analysis.

\section{INTRODUCTION}

The genus Brassica of Brassicaceae family as a whole is believed to have originated around the Mediterranean, Eastern Afghanistan and the adjoining portion of Pakistan and North-Eastern Africa (Hemingway, 1976). The genus includes six economically important species, namely, Brassica rapa, B. oleracea, B. nigra, B. juncea, B. napus, and B. carinata (Doweny and Röbbelen, 1989). Ethiopian mustard is believed to be originated in the highlands of the Ethiopian plateau and the adjoining portion of East Africa and the Mediterranean coast (Gomez-Campo and Prakash, 1999).It evolved as a natural cross between B. nigra $(\mathrm{BB})(\mathrm{n}=8)$ and B. oleracea $(\mathrm{CC})(\mathrm{n}=9)$ and underwent further chromosomal doubling $(2 \mathrm{n}=34 ; \mathrm{UN}, 1935)$. It is partially amphidiploids.

The crop is traditionally used for many purposes, such as greasing traditional bread-baking clay pan, curing certain diseases and as a source of vegetable relish (Nigussie, 2001). It is the only highland oil seed vegetable crop able to consume by defoliating its leaves or sold to generate income after month of sowing in most near big city parts of the country. Crop improvement through plant breeding, thus, occurs through selection operating on genetic variability. Genetic variability is therefore essential for crop improvement. In characterization of Ethiopian mustard for vegetative agro-morphological traits Jane Muthoni, (2010) reported as great variation was seen in leaf number per plant, leaf bloom and leaf blade blistering. Information on the leaves morphological traits of Ethiopian mustard as a leaf vegetable crop is lacking specifically that of time of defoliation to get dual purpose of the crop (leaf and seed). Therefore the present study was, executed with the objective of assessing the extent and 
patterns of genetic variability of Ethiopian mustard land races in relation to topped plant seed yield and its related leafy vegetative agro morphological traits.

\section{Materials AND Methods}

\subsection{Experimental Site}

The experiment was conducted at Holetta Agricultural Research Center (HARC) in 2013/2014 cropping season from June to December 2013. Holetta (West Shewa Zone of Oromia Region) is located at latitude $9^{\circ} \mathrm{N}$ and longitude $38^{\circ} \mathrm{E}$, altitude of $2400 \mathrm{~m}$ a.s.l situated $30 \mathrm{~km}$ West of Addis Ababa. It is one of the representatives of oil seed Brassica growing areas in the central highlands of Ethiopia (Nigussie and Mesfin, 1994). The area has mean annual rainfall of $1059 \mathrm{~mm}$ and temperatures of $23^{\circ} \mathrm{C}$ (maximum) and $8^{\circ} \mathrm{C}$ (minimum). The soil type is Nitisols with soil ph in the range of $6.0-7.5$ (Nigussie and Mesfin, 1994).

\subsection{Description of Test Materials}

A total of forty-nine mustard land races that include one local check and one standard check were used in this study. The majority of the accessions represent the national collection from different major mustard growing regions of the country and that are maintained at Holetta agricultural research Center. The accessions were obtained kindly from Holetta agricultural research center of highland oil crops improvement project. The details of the accessions used in the experiment are given in Table1

Table1. List of 49 Ethiopian mustard genotypes used in the study and their origin.

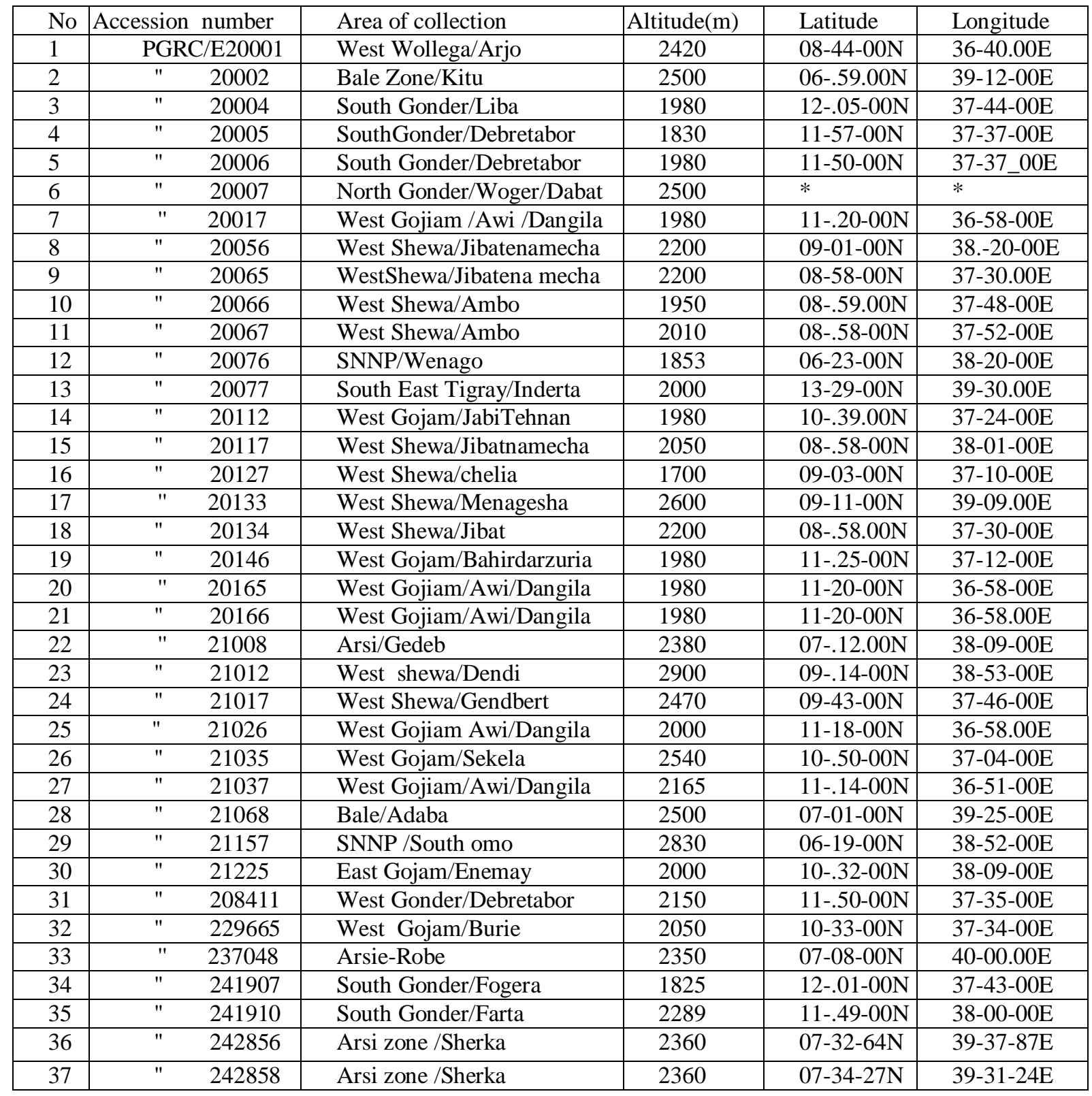


Multivariate Analysis of Genetic Divergent of Ethiopian Mustard (Brasica carinata A. Braun) Landraces in Relation to Leafy Vegetative Agro morphological Traits

\begin{tabular}{|r|rr|l|c|c|c|}
\hline 38 & $"$ & 243738 & South Wollo/Desiezuria & 2928 & $11-08-00 \mathrm{~N}$ & $39-13-00 \mathrm{E}$ \\
\hline 39 & $"$ & 243739 & South Wollo/Tenta & 2950 & $11-.14-00 \mathrm{~N}$ & $39-15-00 \mathrm{E}$ \\
\hline 40 & $"$ & 21256 & West Gojam/Bahirdarzuria & 1940 & $11-16-00 \mathrm{~N}$ & $36-59-00 \mathrm{E}$ \\
\hline 41 & $"$ & 243750 & Wollo/kalu & 2020 & $11-45-00 \mathrm{~N}$ & $39-47.00 \mathrm{E}$ \\
\hline 42 & $"$ & 243756 & South Gonder/ Debark & 3115 & $11-.08 .00 \mathrm{~N}$ & $37-56-00 \mathrm{E}$ \\
\hline 43 & $"$ & 243761 & Gonder Zuria & 2050 & $12-.19-00 \mathrm{~N}$ & $37-33-00 \mathrm{E}$ \\
\hline 44 & $"$ & 243763 & South Gonder/Kemkem & 2070 & $11-57-00 \mathrm{~N}$ & $37-37-00 \mathrm{E}$ \\
\hline 45 & $"$ & 208556 & West Shewa/Adis Alem & 2200 & $*$ & $*$ \\
\hline 46 & $"$ & 208585 & East Shewa/yerer & 1600 & $*$ & $*$ \\
\hline 47 & Yellow dodolla & Bale/Dodolla & 2500 & $06-.59-00 \mathrm{~N}$ & $39-12-00 \mathrm{E}$ \\
\hline 48 & ZemXYelldDodolla) & Cross & 2400 & $09-00-00 \mathrm{~N}$ & $38-00-00 \mathrm{E}$ \\
\hline 49 & Local check & Holetta area & $09-00-00 \mathrm{~N}$ & $38-00-00 \mathrm{E}$ \\
\hline
\end{tabular}

Source: Holetta highland oil crops research program, *=information not found

\subsection{Experimental Design, Management and Season}

The experiment was executed from June 2013 to December 2013. The experiment was laid out in simple lattice design seven by seven with two replications. A plot of four central rows each threemeter long and $30 \mathrm{Cm}$ spacing between rows were used for data collection. Each replication had seven blocks and each block was represented by seven plots. The path between blocks was $2 \mathrm{~m}$ and the spacing between plots with in sub-blocks was also $0.6 \mathrm{~m}$. Each entry was manually drilled, a rate of $10 \mathrm{~kg} / \mathrm{ha}$ and urea and phosphorous fertilizers were applied at the rates of $46 / 69 \mathrm{~kg} / \mathrm{ha} \mathrm{N} / \mathrm{P}_{2} \mathrm{O}_{5}$ respectively. All other recommended agronomic and cultural practices were carried out following practices described by Adefris (2005). Data was collected for Leaf petiole length (cm), Leaf length $(\mathrm{cm})$, Leaf width $(\mathrm{cm})$, Number of leaves per plant, Leaf area index, Leaf Biomass and Seeds yield of leaf defoliated of five plants on days of growth stage of $40^{\text {th }}, 50^{\text {th }}$ and $60^{\text {th }}$.

\subsection{Analysis of Variance}

The data collected for leafy vegetative traits were subjected to analysis of variance (ANOVA) for simple lattice design. Analysis of variance was done using Proc lattice and Proc GLM procedures of SAS version 9.2, (SAS Institute, 2008). Analysis of variance (Table 2) for the considered traits was done using the model for lattice design as follows:

$$
\operatorname{Yil}(j)=u+t i+r j+(b / r) l(j)+e i l(j) \text { Where, } \operatorname{Yil}(j) \text { is the observation of the }
$$

treatment $i\left(i=1, \ldots . V, k^{2}\right)$, in the block $l(l=1, \ldots k)$ of the replication $j(j=1, \ldots, m) ; \mu$ is a constant common to all observations; $t_{i}$ is the effect of the treatment $i ; r j$ is the effect of the replication $j ;(b \mid r)_{1}$ (j) is the effect of the block 1 of the replication $\mathrm{j} ; \boldsymbol{e}_{i l(j)}$ is the error associated to the observation $\mathrm{Y}_{\mathrm{il}(\mathrm{j}) \text {, }}$ where $\mathrm{e}_{\mathrm{i}(\mathrm{j})} \sim \mathrm{N}(0, \mathrm{~s})$ independent.

\subsection{Cluster Analysis for Quantitative Traits}

Clustering of genotypes was performed by canonical roots method using procedures of SAS (SAS Institute, 2008) version 9.20.Software to group sets of genotypes into possible homogenous classes.

\subsection{Genetic Divergence Analysis}

The genetic distances between clusters was estimated by Mahalanobis's (1936) D² statistics using the same software as clustering as:

$$
D^{2} i j=\left(\bar{X}_{i}-\bar{X}_{j}\right)^{1} \operatorname{COV} V^{-1}\left(\bar{X}_{i}-\bar{X}_{j}\right)
$$

Where, $\boldsymbol{D}^{2} \boldsymbol{i j}=$ Total generalized distance between class $\mathrm{i}$ and $\mathrm{j}$

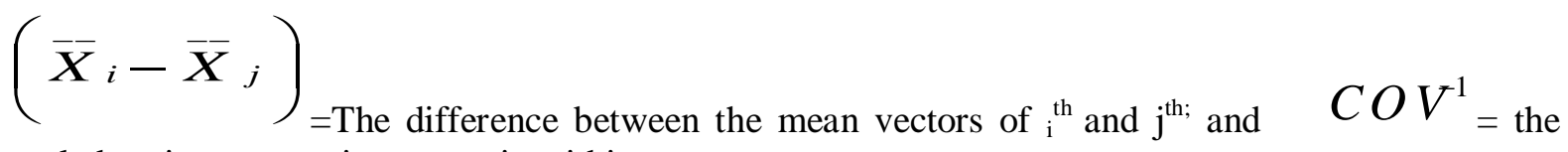

pooled variance-covariance matrix within groups. 
The significance of $\mathrm{D}^{2} \mathrm{ij}$ values for pairs of clusters were tested using the calculated values of chisquare $\left(\mathrm{x}^{2}\right)$ at, $0.01 \%$, and $5 \%$ probability level. The test was done against the tabulated values of $\mathrm{x}^{2}$ for ' $\mathrm{P}$ ' degrees of freedom, where $\mathrm{P}$ is the number of quantitative characters considered (Singh and Chaundhary, 1985)

\section{RESULTS AND DISCUSSION}

\subsection{Analysis of Variance}

The analysis of variance for the 11 leaves morphological traits studied is given in Table 2. The analysis of variance showed that there were significant differences among genotypes for Leaf length, petiole length .leaf width and leaf area traits compared but seed yield per plant, leaf biomass per plant topped at 40, 50 and 60 days of topping and number of intact leaves at flowering showed nonsignificant differences. The significant difference indicates the existence of genetic variability among the accessions that is important for selection and breeding. In characterization of Ethiopian mustard lines for vegetative agro-morphological traits Jane Muthoni, (2010) reported as great variation was seen in leaf number per plant, leaf bloom and leaf blade blistering. At similar manner assessment of genetic variation in this crop was reported by Muhamad et al., ( 2013 for 33 agro-morphological characters.

Table 2. Mean squares for different sources of variations for 11 leave traits of 49 Ethiopian mustard land races

\begin{tabular}{|l|c|c|c|c|}
\hline Characters & Genotype (48) & Block (12) & Replication(1) & Intera-block error (36) \\
\hline Seed yield at 40 date of topping & $0.2544 \mathrm{~ns}$ & 0.1951 & 3.530 & 0.17997 \\
\hline Seed yield at 50 date of topping & $0.245 \mathrm{~ns}$ & 0.2628 & 1.9715 & 0.1314 \\
\hline Seed yield at 60 date of topping & $0.3633 \mathrm{~ns}$ & 0.1902 & 5.7315 & 0.3056 \\
\hline Petiole length & $11.6242^{* *}$ & 2.7005 & 32.229 & 2.6565 \\
\hline Leaf length & $6.1553^{* *}$ & 2.072 & 22.6368 & 2.4629 \\
\hline Leaf width & $5.8638^{* *}$ & 1.8471 & 22.5408 & 2.1336 \\
\hline Leaf area & $7.3403^{* *}$ & 2.0052 & 25.0026 & 2.1764 \\
\hline Number of leaf intact at flowering & $354.12 \mathrm{~ns}$ & 185.86 & 969.26 & 179.31 \\
\hline Leaf biomass at 40 date of topping & $2092.69 \mathrm{~ns}$ & 32923.9 & 9601.02 & 1120.07 \\
\hline Leaf biomass at 50 date of topping & $4322.45 \mathrm{~ns}$ & 3934.41 & 5683.46 & 1957.18 \\
\hline Leaf biomass at 60 date of topping & $3599.61 \mathrm{~ns}$ & 7416.95 & 29440 & 3129.77 \\
\hline
\end{tabular}

*, ** significant at $p=0.05$ and 0.01 significance level, respectively; $n s=$ non-significant

\subsection{Mean and Range Values of Different Traits}

The mean performance of the studied genotypes for 11 vegetative traits are presented in Table 3 . The range of seed yield per plants whose leaves were topped at 40 days of growing was from 2.3 to $3.6 \mathrm{~g}$ of seeds. Among the tested genotypes for leaf topped at 40 days of growing stage 27 genotypes had shown greater seed yield per plants than the grand mean value of topping stage while 19 genotypes showed least mean value and the rest 3 genotypes had shown equal seed yield per plant. The range of seed yield per plants of the leaf topped at 50 days of growing stage was recorded from 1.7 to $3.5 \mathrm{~g}$ of seeds as that of first stage of topping. Among the tested genotypes for leaf topping at 50 days of growing stage 33 genotypes had shown greater or equal seed yield per plants to the grand mean value of its topping stage while 16 genotypes showed less mean value than the grand mean for its topping stage. On the other hand the range of seed yield per plant in plants whose leaves were topped 60 days of growing stage was from 1.6 to $3.4 \mathrm{~g}$. Among the tested genotypes in this category 27 genotypes had showed greater or equal seed yield per plant to the grand mean value while 22 genotypes showed least mean value to the grand mean. The grand mean value showed decrease seed yield per plant when plants were topped at 50 days growth indicating that average seed yield per plant of topped or defoliated plants could be attained by utilization of leafs in this stage of topping. Similarly the mean of petiole length, leaf length, leaf width, leaf area and number of leafs per plant are presented in Table 3. The mean petiole length of the tested genotypes ranged from $2.8 \mathrm{~cm}$ to $11.8 \mathrm{~cm}$. The longest petiole $(11.8 \mathrm{~cm})$ was recorded for the genotype PGRC/E 243756 while the shortest petiole length $(2.8 \mathrm{~cm})$ was recorded for the genotype PGRC/E21068. Similarly mean value leaf length of the tested genotypes ranged from $4.6 \mathrm{~cm}$ to $11.2 \mathrm{~cm}$. The longest leaf length $(11.8 \mathrm{~cm})$ was recorded for the genotype PGRC/E243756 while the shortest leaf length $(4.6 \mathrm{~cm})$ was recorded for the genotype PGRC/E 21068.The mean value for Leaf width ranges from $2.1 \mathrm{~cm}$ for genotype PGRC/E 21068 and $8.8 \mathrm{~cm}$ for the genotype PGRC/E 2243756.The mean value of leaf area for the tested genotypes also 
Multivariate Analysis of Genetic Divergent of Ethiopian Mustard (Brasica carinata A. Braun) Landraces in Relation to Leafy Vegetative Agro morphological Traits

ranges $3.1 \mathrm{~cm}$ for the genotype PGRC/E21068 to $10.6 \mathrm{~cm}$ for the genotype PGRC/E243756. Among the tested genotypes for petiole length, leaf length, leaf width and leaf area the mean value of all these characters indicated that genotype PGRC/E 243756 was the first. The mean value of leaf biomass at 40 days topping ranged $34 \mathrm{~g}$ for the genotype PGRC/E20133 and $191 \mathrm{~g}$ for the genotype PGRC/E20166. Mean value of leaf biomass weight at 50 days of growing period topping ranges $43 \mathrm{~g}$ for the genotype PGRC/E21008 and $243 \mathrm{~g}$ for the genotype PGRC/E20017. The mean value of leaf biomass for 60 days of growing period was recorded with the range value of $57 \mathrm{~g}$ for genotype PGRC/E20133 to 226g for genotype PGRC/E20001.The mean value of leaf biomass topped or defoliated shows trend of increasing by indicating that seed yield of defoliated plants after 50 days of topping shows in yield declining. The last leaf vegetative parameter studied was number of intact leaves at vegetative stage of life cycle growth of the mustard genotypes. The mean value for number leaves intact at vegetative growth stage was recorded from the mean range of 45 for the genotype PGRC/E20127 to 108 for genotype PGRC/E 208585.

Table 3. Mean and range values of the studied 49 genotypes for 11 leaves vegetative and its related trait tested at Holetta, 2013

\begin{tabular}{|c|c|c|c|c|c|c|c|c|c|c|c|c|}
\hline No & $\begin{array}{l}\text { Genotype } \\
\text { Code }\end{array}$ & $\begin{array}{l}\text { ySY } \\
\text { 40DT }\end{array}$ & $\begin{array}{l}\text { SY } \\
50 \mathrm{DT}\end{array}$ & $\begin{array}{l}\text { SY } \\
60 \mathrm{DT}\end{array}$ & PL & LL & LW & LA & $\begin{array}{l}\text { LB } \\
\text { 40DT }\end{array}$ & $\begin{array}{l}\text { LB } \\
50 \mathrm{DT}\end{array}$ & $\begin{array}{l}\text { LB } \\
60 \mathrm{DT}\end{array}$ & NOL \\
\hline 1 & PGRC/E20001 & 3.6 & 2.9 & 2.9 & 8.2 & 10.5 & 6.0 & 8.2 & \begin{tabular}{|l}
94 \\
\end{tabular} & \begin{tabular}{|l|}
168 \\
\end{tabular} & 226 & 69 \\
\hline 2 & 20002 & 3.2 & 2.7 & 3.0 & 4.0 & 5.5 & 3.3 & 4.2 & 76 & 130 & 127 & 54 \\
\hline 3 & 20004 & 3.3 & 2.9 & 2.9 & 5.3 & 8.2 & 4.6 & 6.1 & 65 & 168 & 97 & 81 \\
\hline 4 & 20005 & 3.0 & 2.9 & 2.5 & 5.8 & 6.8 & 4.6 & 5.7 & 69 & 223 & 169 & 90 \\
\hline 5 & 20006 & 3.6 & 2.3 & 2.8 & 8.2 & 8.9 & 6.5 & 7.8 & 93 & 148 & 208 & 74 \\
\hline 6 & 20007 & 3.0 & 2.5 & 2.4 & 5.7 & 8.1 & 5.0 & 6.3 & 109 & 156 & 147 & 69 \\
\hline 7 & 20017 & 3.6 & 3.4 & 2.3 & 7.1 & 9.6 & 6.2 & 7.6 & 107 & 243 & 150 & 69 \\
\hline 8 & 20056 & 3.3 & 2.7 & 3.0 & 8.1 & 7.4 & 6.0 & 7.2 & 50 & 74 & 189 & 53 \\
\hline 9 & 20065 & 3.5 & 2.5 & 1.7 & 11.1 & 10.3 & 6.8 & 9.4 & 73 & 113 & 196 & 62 \\
\hline 10 & 20066 & 3.5 & 3.0 & 2.8 & 10.4 & 10.5 & 8.0 & 9.7 & 121 & 84 & 201 & 76 \\
\hline 11 & 20067 & 3.5 & 2.8 & 2.3 & 5.8 & 7.6 & 4.7 & 6.1 & 125 & 97 & 104 & 83 \\
\hline 12 & 20076 & 3.4 & 2.9 & 2.8 & 7.5 & 9.4 & 5.6 & 7.5 & 124 & 160 & 139 & 61 \\
\hline 13 & 20077 & 3.6 & 2.9 & 3.0 & 5.7 & 7.7 & 4.1 & 5.8 & 91 & 173 & 134 & 64 \\
\hline 14 & 20112 & 3.2 & 2.6 & 2.3 & 6.6 & 8.8 & 6.9 & 7.5 & 138 & 163 & 152 & 57 \\
\hline 15 & 20117 & 3.2 & 2.7 & 2.5 & 8.8 & 9.6 & 7.0 & 8.5 & 53 & 136 & 156 & 78 \\
\hline 16 & 20127 & 3.3 & 2.5 & 2.0 & 10.2 & 10.6 & 7.4 & 9.4 & 60 & 105 & 102 & 45 \\
\hline 17 & 20133 & 2.7 & 2.7 & 1.4 & 3.7 & 5.8 & 3.2 & 4.2 & 34 & 96 & 57 & 67 \\
\hline 18 & 20134 & 3.4 & 2.8 & 2.0 & 11.2 & 11.1 & 8.1 & 10.1 & 128 & 118 & 153 & 68 \\
\hline 19 & 20146 & 3.0 & 2.7 & 2.6 & 5.8 & 8.8 & 5.8 & 6.9 & 67 & 141 & 120 & 52 \\
\hline 20 & 20165 & 3.5 & 3.5 & 2.4 & 8.1 & 10.3 & 7.2 & 8.5 & 118 & 126 & 136 & 64 \\
\hline 21 & 20166 & 3.5 & 3.3 & 2.6 & 6.8 & 8.7 & 5.8 & 7.1 & 191 & 197 & 185 & 68 \\
\hline 22 & 21008 & 2.8 & 2.2 & 2.7 & 4.2 & 5.9 & 3.3 & 4.4 & 74 & 43 & 122 & 89 \\
\hline 23 & 21012 & 2.9 & 2.7 & 2.8 & 7.9 & 8.4 & 6.3 & 7.5 & 106 & 109 & 168 & 80 \\
\hline 24 & 21017 & 2.6 & 2.2 & 2.4 & 9.4 & 9.4 & 7.0 & 8.6 & 154 & 106 & 158 & 71 \\
\hline 25 & 21026 & 3.1 & 3 & 2.8 & 7.0 & 9.0 & 6.7 & 7.5 & 148 & 90 & 134 & 61 \\
\hline 26 & 21035 & 2.3 & 2.9 & 1.6 & 11.7 & 10.9 & 8.4 & 10.3 & 122 & 93 & 97 & 72 \\
\hline 27 & 21037 & 3.0 & 3.1 & 2.8 & 9.0 & 9.9 & 7.1 & 8.7 & 114 & 120 & 137 & 71 \\
\hline 28 & 21068 & 2.9 & 2.9 & 1.9 & 2.8 & 4.6 & 2.1 & 3.1 & 111 & 82 & 139 & 60 \\
\hline 29 & 21157 & 2.8 & 2.3 & 2.0 & 10.1 & 10.4 & 7.6 & 9.4 & 100 & 151 & 145 & 70 \\
\hline 30 & 21225 & 3.3 & 2.8 & 2.4 & 3.0 & 6.0 & 2.6 & 3.8 & 108 & 105 & 111 & 66 \\
\hline 31 & 208411 & 3.4 & 3.3 & 2.2 & 6.7 & 8.0 & 5.3 & 6.7 & 76 & 152 & 109 & 89 \\
\hline 32 & 229665 & 2.6 & 2.7 & 2.4 & 8.5 & 11.0 & 8.2 & 9.2 & 70 & 86 & 187 & 90 \\
\hline 33 & 237048 & 2.3 & 2.8 & 2.5 & 10.5 & 10.9 & 8.1 & 9.8 & 94 & 84 & 125 & 67 \\
\hline 34 & 241907 & 2.8 & 3.3 & 2.4 & 6.4 & 8.1 & 5.7 & 6.8 & 136 & 132 & 154 & 89 \\
\hline 35 & 241910 & 2.7 & 3.0 & 2.7 & 6.9 & 8.0 & 5.5 & 6.8 & 88 & 139 & 181 & 84 \\
\hline 36 & 242856 & 3.3 & 3.0 & 2.8 & 6.2 & 7.7 & 4.5 & 6.1 & 82 & 160 & 184 & 56 \\
\hline 37 & 242858 & 3.1 & 2.9 & 2.7 & 10.0 & 9.5 & 6.3 & 8.6 & 89 & 240 & 196 & 75 \\
\hline 38 & 243738 & 2.8 & 2.8 & 2.6 & 4.4 & 6.8 & 3.7 & 4.9 & 87 & 174 & 126 & 80 \\
\hline 39 & 243739 & 3.6 & 2.3 & 2.6 & 4.5 & 5.7 & 3.4 & 4.5 & 82 & 128 & 164 & 67 \\
\hline 40 & 21256 & 2.9 & 2.2 & 2.8 & 10.0 & 11.1 & 8.1 & 9.8 & 81 & 202 & 167 & 76 \\
\hline 41 & 243750 & 3.1 & 2.6 & 2.1 & 5.1 & 7.4 & 4.4 & 5.6 & 122 & 132 & 155 & 74 \\
\hline 42 & 243756 & 3.2 & 2.1 & 1.6 & 11.8 & 11.2 & 8.8 & 10.6 & 94 & 120 & 222 & 48 \\
\hline
\end{tabular}


Fekadu Amsalu et al.

\begin{tabular}{|c|c|c|c|c|c|c|c|c|c|c|c|c|}
\hline 43 & " 243761 & 2.5 & 2.2 & 2.3 & 9.1 & 8.9 & 6.6 & 8.2 & 133 & 146 & 210 & 55 \\
\hline 44 & " 243763 & 3.0 & 1.7 & 2.3 & 6.9 & 7.5 & 5.4 & 6.6 & 140 & 109 & 111 & 58 \\
\hline 45 & " 208556 & 3.5 & 2.6 & 2.3 & 6.1 & 7.5 & 5.1 & 6.2 & 63 & 117 & 98 & 77 \\
\hline 46 & PGRC/E & 3.5 & 2.8 & 3.0 & 9.6 & 10.0 & 7.8 & 9.1 & 158 & 202 & 108 & 108 \\
\hline 47 & Yellow dodolla & 3.5 & 2.8 & 3.4 & 5.2 & 6.9 & 4.4 & 5.5 & 82 & 216 & 213 & 60 \\
\hline 48 & $\begin{array}{l}\text { (ZemXYellow } \\
\text { Dodolla) }\end{array}$ & 3.3 & 2.7 & 3.1 & 5.0 & 7.2 & 4.2 & 5.4 & 123 & 126 & 122 & 100 \\
\hline 49 & Local check & 3.3 & 2.3 & 2.5 & 3.9 & 6.0 & 3.4 & 4.4 & 85 & 96 & 98 & 81 \\
\hline Range & & 2.3-3.6 & $\begin{array}{l}1.7- \\
3.5\end{array}$ & $1.6-3.4$ & $2.8-11.8$ & $4.6-11.2$ & $2.1-8.8$ & $3.1-10.6$ & $34-191$ & $43-243$ & $57-226$ & $\begin{array}{l}45- \\
108\end{array}$ \\
\hline Mean & & 3.1 & 2.7 & 2.5 & 7.2 & 8.5 & 5.7 & 7.2 & 100 & 137 & 149 & 71 \\
\hline $\begin{array}{l}\mathrm{CV} \\
(\%)\end{array}$ & & 13.59 & 12.68 & 22.4 & 22.5 & 18.4 & 20.6 & 36.8 & 33.4 & 32.46 & 37.61 & 36.75 \\
\hline $\begin{array}{c}\mathrm{LSD}( \\
0.05)\end{array}$ & & 0.853 & 0.741 & 1.111 & 3.77 & 3.155 & 2.966 & 57.37 & 73.26 & 95.19 & 0.529 & 57.37 \\
\hline
\end{tabular}

YD, Yellow Dodolla, Sy40DT, SY50DT, SY 60DT=Seed yield of $(40,50,60)$ days of toping, PL, LL, LW = Petiole, leaf, width length respectively, LA= leaf area and LB40, LB50, LB60=Leaf biomass at (40, 50. 60 )days of topping per plants: NOL=number of leaf intact at vegetative stage/ flowering stag

\subsection{Multivariate Analyses}

\subsubsection{Clustering of Genotypes using Leaf Vegetative Traits}

Clustering based on leaf vegetative traits made on 49 genotypes is presented in Table 4. Cluster1 consists the largest of all included 33 (67.34\%) genotypes that comprised nine genotypes of West Shewa, eight genotypes from West and East Gojam, six genotypes of South and North Gonder, two genotypes each from Arsie zone and Southern Nation's Nationalities People, three genotypes from South Wollo, one each from South Tigray, Bale zone, and cross. The second cluster comprises nine (18.36\%) genotypes three of each from South Gonder and Shewa, one each from East Gojam, Arsiezone and West Wollega. Cluster3 comprised 5(10.20\%) genotypes. Two Genotypes were from West Gojam, one genotype each from South Gonder, Arsiezone and standard check. Cluster 4 comprised genotypes that were origins of one from East Shewa and West Gojam. The produced a clear grouping of the 49 genotypes into four clusters, where by the individuals within any one cluster are more closely related than other individuals in different clusters. In leafy vegetative traits clustering the highest $67.34 \%$ of the genotypes were grouped in $\mathrm{C} 1$ followed by $18.36 \%$ in $\mathrm{C} 2,10.20 \%$ in C3 and $4.08 \%$ in $\mathrm{C} 4$. Based on this clustering, genotypes with the same geographic origin were grouped in the same cluster. This phenomenon might have resulted from their similar genetic background. On the other hand, there are also genotypes with same geographical origin but grouped in different clusters which might be due to difference in their genetic background. All checks were grouped in different clusters, i.e. Local check under $\mathrm{C} 1$ and standard check under $\mathrm{C} 3$, which indicates that these varieties may have different relationship with the genotypes in their respective clusters. Besides, genotypes with different geographical origin were grouped in same cluster which might have been as a result of the difference in selection pressure applied on different components of various geographical areas which might coincide resulting in clustering together of genotypes which have been collected at different area.

Table4. Distribution of 49 Ethiopian mustard genotypes in different clusters based on their leafy vegetative traits.

\begin{tabular}{|c|c|c|}
\hline $\begin{array}{l}\text { Cluster } \\
\text { Cluster I }\end{array}$ & $\begin{array}{l}\text { No. of } \\
\text { genotypes }\end{array}$ & $\begin{array}{l}\text { Genotypes included by code and origin } \\
\text { 20(Gojam),27(Gojam),6(Gonder),29(Sidamo),11(Shewa),26((Gojam)),2(Bale), } \\
\text { 19((Gojam)),13(Tigray),38(wollo),18(Shewa),41(Wollo),12(Sidamo),14(Gojam), } \\
\text { 3(Gonder),31(Gonder),28(Bale),33(Arsie),30((Gojam)),35(Gonder),39(Wollo), } \\
\text { 34(Gonder),45(Shewa),49(Shewa),25((Gojam)),44(Gonder),23(Shewa),48(cross), } \\
\text { 16(Shewa),15(Shewa),24(Shewa), 17(Shewa),22(Arsie), }\end{array}$ \\
\hline Cluster II & 9 & $\begin{array}{l}\text { 1(Wolega),5(Gonder),9(Shewa),42(Gonder),36(Arsie),8(Shewa),32(Gojam), } \\
\text { 43(Gonder), 10(Shewa). }\end{array}$ \\
\hline Cluster III & 5 & 4(Gonder), 40(Gojam), 37(Arsie), 47(Bale), 7(Gojam). \\
\hline Cluster IV & 2 & 21 (Gojam), 46(Shewa). \\
\hline
\end{tabular}


Multivariate Analysis of Genetic Divergent of Ethiopian Mustard (Brasica carinata A. Braun) Landraces in Relation to Leafy Vegetative Agro morphological Traits

\subsubsection{Cluster Mean for Leafy Traits, Distance and Component Analysis}

\section{Cluster Means for leafy Vegetative Traits}

Intra-class genetic divergence of Ethiopian mustard land races for leafy vegetative traits is shown in Table 5. Genotypes in Cluster 4 showed high seed yield per plants of leaf toped at 40, 50 and 60 days of growth stage of genotypes than other clusters. The least seed yield per plants of leaf toped at 40, 50 and 60 days of growth stage of genotypes were found in Cluster 1 of SY60DT (2.4gm) than other topping stages of the study. On the other hand Cluster 2 showed much lengthier in petiole length (9.1), leaf length (9.6), leaf width (6.8) and leaf area $\left(8.5 \mathrm{~cm}^{3}\right)$ than other clusters. But leaf width of Cluster 2 and Cluster 4 was found similar $\left(6.8 \mathrm{~cm}^{3}\right)$. Genotypes in Cluster 3 showed more leaf biomass weight per plants of leaf topped at 50 days of growth stage of genotypes than others. Similarly high intact number of leafs per plant during vegetative stage of growth/flowering stage was observed from Cluster 4 (88) following Cluster 3(74) and Cluster 1(71) genotypes.

Table 5. Clusters mean for leaf vegetative traits of the Ethiopian Mustard genotypes.

\begin{tabular}{|l|c|c|c|c|}
\hline & \multicolumn{4}{|c|}{ Cluster } \\
\hline Traits & Cluster 1 & Cluster2 & Cluster3 & Cluster4 \\
\hline & Mean & Mean & Mean & Mean \\
\hline Seed yield at 40 date of topping & 3.1 & 3.2 & 3.2 & 3.5 \\
\hline Seed yield at 50 date of topping & 2.7 & 2.6 & 2.8 & 3.1 \\
\hline Seed yield at 60 date of topping & 2.4 & 2.5 & 2.7 & 2.8 \\
\hline Petiole length & 6.7 & 9.1 & 7.6 & 8.2 \\
\hline Leaf length & 8.2 & 9.6 & 8.8 & 9.4 \\
\hline Leaf width & 5.4 & 6.8 & 5.9 & 6.8 \\
\hline Leaf area & 6.7 & 8.5 & 7.4 & 8.1 \\
\hline Leaf biomass at 40 date of topping & 101 & 90 & 86 & 175 \\
\hline Leaf biomass at 50 date of topping & 123 & 122 & 225 & 200 \\
\hline Leaf biomass at 60 date of topping & 130 & 203 & 179 & 147 \\
\hline Number of leaf intact at flowering & 71 & 65 & 74 & 88 \\
\hline
\end{tabular}

\subsection{Distance Analysis among Genotypes using Leaf Vegetative Traits}

The pair wise generalized squared distance (D2) among the clusters based on leaf vegetative traits are presented in Table 6. Genetic distances were highly significant between Cluster 2 and Cluster 4 . The highest genetic distance was recorded between Cluster 2 and

Cluster 4 (46.26) followed by Cluster 1 and Cluster 4 (22.92), and Cluster 3 and Cluster 4 (22.08). The genetic divergence between Cluster 1 and Cluster 2, Cluster 1 and Cluster 3, Cluster 1 and Cluster 4 were also significant. Genetic distances of genotypes based on leaf vegetative traits between Cluster 2 and Cluster 3 were non significant, indicating close relationship among the genotypes.

Table 6. Pair wise generalized squared distance (D2) among 49 genotypes of Ethiopian mustard in four clusters based on their leafy vegetative traits.

\begin{tabular}{|l|l|l|l|l|}
\hline \multirow{2}{*}{ Cluster } & \multicolumn{4}{|c|}{ Cluster } \\
\cline { 2 - 5 } & Cluster 1 & Cluster 2 & Cluster 3 & Cluster4 \\
\hline Cluster 1 & 0 & $13.81^{* *}$ & $17.73^{*}$ & $22.92^{* * *}$ \\
\hline Cluster 2 & & 0 & $20.83 \mathrm{n}$ s & $46.26^{* *}$ \\
\hline Cluster 3 & & & 0 & $22.08^{* *}$ \\
\hline Cluster 4 & & & & 0 \\
\hline
\end{tabular}

\subsection{Principal Component Analyses}

In order to assess the patterns of variations of principal component analysis (PCA) was done by considering 11 traits for leaf vegetative traits. Principal component analyses are presented in Tables 7. Principal component analysis showed that $88.18 \%$ of the variation was contributed by the first five principal components for leaf vegetative traits. Leaf area, leaf width, leaf length and petiole length, were the major seed yield positive contributors of the variation in the first principal component in which $39.53 \%$ of the variation revealed. Leaf area and leaf width had relatively high positive weight. In Component 1 there was no negative weight record. Additional $24.10 \%$ variation in the second principal component was mainly observed through trait such as leaf width and leaf length. The third 
principal component accounted for another additional $12.20 \%$ of the variation in which petiole length and leaf area was the major contributor. Principal component 4 and 5 contributed $7.94 \%$ and $4.41 \%$ additional variations respectively. Leaf length in principal component 4 was among the major contributors. Leaf length and leaf area in principal component component 5 had the most negative weight. In general, it is assumed that traits with larger absolute values closer to unity within the first principal component influence the clustering more than those with lower absolute values closer to zero (Chahal and Gosal, 2002). In this study, most of the traits individually contributed small effects $( \pm 0.419-0.09)$ to the total variation and, therefore, differential grouping of genotypes was mainly attributed by the cumulative effect of the individual traits.

Table7. Component scores of the first five principal components of 49 genotypes of Ethiopian mustard based on their leaves vegetative traits

\begin{tabular}{|l|c|c|c|c|c|}
\hline & \multicolumn{4}{|c|}{ Component scores } & Principal \\
\hline Traits & $\begin{array}{c}\text { Principal } \\
\text { component 1 }\end{array}$ & $\begin{array}{c}\text { Principal } \\
\text { component 2 }\end{array}$ & $\begin{array}{c}\text { Principal } \\
\text { component 3 }\end{array}$ & $\begin{array}{c}\text { Principal } \\
\text { component 4 }\end{array}$ & \begin{tabular}{c} 
component 5 \\
\hline Petiole length
\end{tabular} \\
\hline Leaf length & 0.407 & -0.050 & 0.086 & 0.052 & -0.085 \\
\hline Leaf width & 0.408 & 0.043 & 0.031 & 0.078 & -0.102 \\
\hline Leaf area & 0.419 & 0.032 & 0.030 & 0.019 & -0.085 \\
\hline Eigen value & 5.53 & 0.002 & 0.053 & 0.047 & -0.09 \\
\hline Variance (\%) & 39.53 & 24.10 & 1.71 & 1.11 & 0.62 \\
\hline Cumulative (\%) & 39.53 & 63.63 & 75.83 & 83.77 & 4.41 \\
\hline
\end{tabular}

\section{Conclusion}

In this study, 49 Ethiopian mustard genotypes acquired from diverse zones/regions of Ethiopia were evaluated in simple lattice design with two replications at Holetta Agricultural Research Center, West Shewa zone, with the objective of estimating leafy vegetative agro-morphological traits, topped plants of seed yield and its related characters, to assess genetic diversity through morphological traits .The analysis of variance showed the presence of highly significant differences among the tested genotypes for Leaf area, leaf width, leaf length and petiole length of characters considered, indicating the existence of variability among the tested genotypes for these characters. The grand mean value shows a decrease mean value for seed yield per plant from growth stage of $50^{\text {th }}$ days of topping of leafs to $60^{\text {th }}$ day of growth stage of topping indicating that average seed yield per plant of topped or defoliated could be attained by utilization of leaves in this stage of topping. Petiole length has shown significant positive correlation with leaf length, leaf width, and leaf area and leaf biomass of topped at $60^{\text {th }}$ days of growth stage. Similarly leaf length shown significant positive correlation for leaf width, leaf area and leaf biomass of topped at $60^{\text {th }}$ days of growth stage. Multivariate Analyses of genetic divergence of Ethiopian mustard genotypes for leafy vegetative traits have resulted in the formation of four clusters and have shown genetic variability for further selection and breeding improvement work. Genotypes in C4 showed high seed yield per plants of leaf toped at $40^{\text {th }}, 50^{\text {th }}$ and $60^{\text {th }}$ days of growth stage of genotypes than other clusters. The least seed yield per plants of leaf toped at $40^{\text {th }}, 50$ th and 60th days of growth stage of genotypes was found in C1 of SY60DT (2.4g) than other topping stages of the study. On the other hand C2 showed much lengthier in petiole length (9.1), leaf length (9.6), leaf width (6.8) and leaf area $\left(8.5 \mathrm{~cm}^{3}\right)$ than other clusters. Genotypes in $\mathrm{C} 3$ showed more leaf biomass weight per plants of leaf topped at 50 days of growth stage of genotypes than others. Similarly high intact number of leafs per plant during vegetative stage of growth stage was observed from C4 (88) following C3 (74) and C1 (71) genotypes. From the present investigation, we could also found that geographical diversity could not necessarily be an index of genetic variability, and the factors other than geographic diversity such as genetic drift, selection pressure and environment may be responsible for differential grouping of genotypes. The present study revealed the presence of considerable variability among genotypes for Leaf area, leaf width, leaf length and petiole length traits compared but none significant for seed yield per plant, leaf biomass per plant topped at 40,50 and 60 days of topping and number of intact leaves at flowering. These conditions indicate that there is good opportunity to improve these characters using the tested genotypes.

\section{ACKNOWLEDGMENT}

The first author acknowledges Jimma University of College of agriculture and Veterinary Medicine and Embassy of Netherland in Ethiopia for their sponsoring fund to conduct field experiment. 


\section{REFERENCES}

[1] Adefris Teklewold. 2005. Diversity Study Based on Quality Traits and RAPD Markers and Investigation of Heterosis in Ethiopian Mustard. Ph.D. diss. Georg-August Univ. of Göttingen, Germany. 161p.

[2] Chahal, G.S. and S.S. Gosal. 2002. Principles and procedures of plant breeding: biotechnological and conventional approaches. Narosa Publishing House, New Delhi.

[3] Doweny R.K. and G. RÖbbelen. 1989. Brassica Species. In RÖbbelen G, Doweny RK and Ahri A (eds) Oil crops of the world. McGraw-Hill New York. pp. 339-359

[4] Gomez-Campo, C. and S. Prakash. 1999. Origin and domestication of the Brassica. pp. 33-58. In: Gomez-Campo C (ed.). Biology of Brassica Coenospecies. Elsevier, Amsterdam.

[5] Hemingway, J.S. 1976. Mustards Brassica species and Sinapsis alba (Cruciferae). In: Evolution of Crop Plants. N.W. Simmounds (ed.) Longan. London. 339p.

[6] Jane Muthoni.2010.Characterization of Ethiopian Mustard(Brassica carinata A. Braun)lines for vegetative agro morphological traits at Arusha, Tanzania. Jornal of Horti and forestry Vol.2(1)pp.002006

[7] Mahalanobis, P.C. 1936. On the generalized distance in statistics.Proc. Natl. Sci. India B. 2: 4955

[8] Muhamad Zat, Nahida Zakir, Ashia Rabbani and Zabat Shinwari ,2013. Assesement of genetic variation in Ethiopian Mustard (Brassica carinata A. Braun) gerplasm using multivariate techniques .pak. J. Bot 45(51)583-593.

[9] Nigussie Alemayehu. 2001. Germplasm diversity and Genetics of Quality and Agronomic Traits in Ethiopian Mustard (Brassica carinata A. Braun). Ph.D. Thesis, George-August University of GÖttingen, Germany

[10] Nigussie Alemayehu and Mesfin Abebe. 1994. Relative importance of some management factors in seed and oil yields of Ethiopian mustasrd (Brasica carinata Braun.) and Rapeseed (Brasica napus L.). Ethiop. J. Agric. Sci. 14: 27-36

[11] SAS Institute INC., 2002- 2008. SAS*STAT, users guide, version 9.2, Cary N.C., SAS INC

[12] Singh, R.K. and B.D. Chaydhary. 1985. Biometrical methods in quantitative genetic analysis

[13] U.N. 1935. Genome analysis in Brassica with special reference to the experimental formation of $B$. napus and peculiar mode of fertilization. Jpn. J. Bot. 9: 389-452.

Citation: F. Amsalu, et al. "Multivariate Analysis of Genetic Divergent of Ethiopian Mustard (Brasica carinata A. Braun) Landraces in Relation to Leafy Vegetative Agro morphological Traits", International Journal of Research Studies in Agricultural Sciences (IJRSAS), vol. 3, no. 7, p. 9, 2017. http: //dx.doi.org /10.20431/2454-6224.0307002

Copyright: (c) 2017 Authors. This is an open-access article distributed under the terms of the Creative Commons Attribution License, which permits unrestricted use, distribution, and reproduction in any medium, provided the original author and source are credited. 